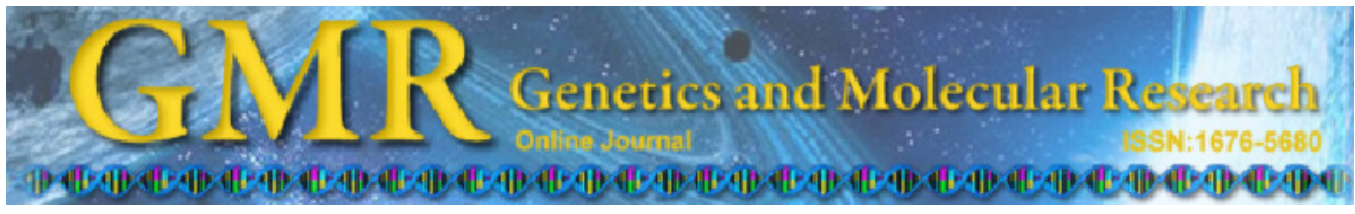

\title{
Isolation and characterization of 16 microsatellite loci in marble goby (Oxyeleotris marmoratus)
}

\author{
J. Luo ${ }^{1}$, X.P. Zhu ${ }^{1}$, Y.H. Peng ${ }^{1}$ and S.W. Yin ${ }^{1,2}$ \\ ${ }^{1}$ Key Laboratory of Tropical Biological Resources, Ocean College, \\ Hainan University, Ministry of Education, Haikou, China \\ ${ }^{2}$ College of Life Sciences, Nanjing Normal University, Nanjing, China \\ Corresponding author: S.W. Yin \\ E-mail: yinshaowu@163.com
}

Genet. Mol. Res. 12 (2): 2020-2023 (2013)

Received February 15, 2012

Accepted August 24, 2012

Published January 4, 2013

DOI http://dx.doi.org/10.4238/2013.January.4.2

\begin{abstract}
A microsatellite-enriched genomic library for marble goby (Oxyeleotris marmoratus), a freshwater fish of considerable economic value, was obtained. A total of 16 microsatellite markers were successfully isolated and characterized in a population from the Mekong River in Vietnam. These markers had 2-20 alleles with expected heterozygosity ranging from 0.0370 to 0.8927 . Linkage equilibrium was observed in most loci, and only 1 locus revealed a significant deviation from Hardy-Weinberg equilibrium. These microsatellite markers will be useful for genetic diversity and molecular marker-assisted selection studies of wild and farmed $O$. marmoratus.
\end{abstract}

Key words: Oxyeleotris marmoratus; Microsatellite loci; Magnetic-bead enrichment 


\section{INTRODUCTION}

The marble goby (Oxyeleotris marmoratus), commonly known as Soon Hock, is the largest species of goby-like fishes (Smith, 1945). It is native to the Mekong and Chao Phraya River basins, Malay Peninsula, Indonesia, and the Philippines (Kottelat, 1993). O. marmoratus is considered a superior-quality freshwater fish with high market demand and commercial value. Owing to its high price and cultivation potential, marble goby culture has been rapidly developed in Southeast Asian countries such as Thailand, Vietnam, Malaysia, and China. Many studies have been conducted on artificial culture, larval rearing, and nutrition physiology (Vu et al., 2005; Su et al., 2008; Nakagawa et al., 2009). However, genetic studies on the species have rarely been reported. Only 8 simple sequence repeat (SSR) primers have been developed for O. marmoratus (Abercrombie et al., 2009). Those loci with few alleles (2-4) are inadequate for further population genetic analysis and breeding studies.

Microsatellites or SSRs exist in both coding and noncoding regions of prokaryotic and eukaryotic genomic DNA. SSRs are usually characterized by a high degree of length polymorphism (Zane et al., 2002). Herein, we report a set of 16 polymorphic microsatellite loci and primers for $O$. marmoratus obtained using the method of fast isolation by amplified fragment length polymorphism of sequences containing repeats. These markers will be useful for genetic diversity and molecular marker-assisted selection studies of wild and farmed $O$. marmoratus.

\section{MATERIAL AND METHODS}

An enrichment library was constructed using a protocol described by Zane et al. (2002). Genomic DNA was extracted from tail fin tissues of 3 individuals using a standard proteinase $\mathrm{K} / \mathrm{phenol}$ extraction protocol. Three $10 \mu \mathrm{g}$ DNA samples were pooled and digested with Bsp143I restriction enzyme. Size fractions of 400-1000 bp were selected and ligated to adaptors: oligo A (5'-GCGGTACCCGGGAAGCTTGG-3') and oligo B (5'-GATCCCAAGCTTCCCGGGTACCGC-3') (Moraga et al., 1998). Pre-hybridization polymerase chain reaction (PCR) amplification was performed for the digested/ligated library using oligo A. For enrichment, the DNA was denatured and hybridized with 2 biotinylated probes [B-ATAGAATAT $(\mathrm{CA})_{15}$ and B-ATAGAATAT $(\mathrm{GA})_{15}$ ] at $68^{\circ} \mathrm{C}$ for $1 \mathrm{~h}$. The fragments hybridized to the probes were then captured with streptavidin-coated magnetic beads (Streptavidin Magnesphere Paramagnetic Particles, Promega, Madison, WI, USA).

After enrichment, nonspecific binding and unbound DNAs were removed with several nonstringent and stringent washes. The microsatellite-enriched DNA fragments were collected and amplified with PCR and then ligated to T-vectors (pMD18-T, Takara, Dalian, China) and transformed into DH5 $\alpha$ competent cells. Transformed cells grew at $37^{\circ} \mathrm{C}$ overnight on a Luria-Bertani agar plate containing ampicillin, $\mathrm{X}$-gal, and isopropyl-beta-D-thiogalactopyranoside for blue/white selection. The positive clones were selected for post-PCR using M13/RV-p and (CA) $)_{12} /(\mathrm{GA})_{12}$ primers and sequenced on an ABI 3730 Genetic Analyzer (Applied Biosystems). SSRs were detected using the SSRHunter 1.0 software (Li and Wan, 2005). All of these loci were deposited in GenBank.

Primers were designed using the Primer Premier 5.0 software (Premier Biosoft International, Palo Alto, CA, USA). The primer pairs (fluorescence-labeled at the 5'-end) were tested on 53 individuals of $O$. marmoratus collected from the Mekong River in Vietnam. The allele number per locus $\left(N_{\mathrm{A}}\right)$, allele size range, observed heterozygosity $\left(H_{\mathrm{O}}\right)$, and expected heterozygosity 
$\left(H_{\mathrm{E}}\right)$ were calculated using Popgene 1.31 (Yeh et al., 1999). Deviations from Hardy-Weinberg expectations were estimated using Genepop4.0 (Raymond and Rousset, 1995; Rousset, 2008).

\section{RESULTS AND DISCUSSION}

A total of 205 positive clones were selected for post-PCR, and 127 were successfully sequenced. Among the 127 clone sequences, 81 (64\%) contained simple or compound microsatellites with 9 or more repeats. All of these loci were deposited in GenBank. Primers were tested on the genomic DNA of marble goby, and 29 primer pairs successfully revealed consistent amplification and polymorphic loci. The variability of 16 selected loci from 29 primer pairs (fluorescence-labeled at the 5 '-end) was tested on 53 individuals of $O$. marmoratus.

$N_{\mathrm{A}}$, allele size range, $H_{\mathrm{O}}, H_{\mathrm{E}}$, and deviations from Hardy-Weinberg expectations are listed in Table 1. $N_{\mathrm{A}}$ ranged from 2 to 20 , and $H_{\mathrm{O}}$ and $H_{\mathrm{E}}$ ranged from 0.0377 to 0.8491 and 0.0370 to 0.8927 , respectively. No evidence of linkage disequilibrium between locus pairs was observed. One locus showed significant departure from Hardy-Weinberg equilibrium (P $<0.05$ ), which might have been due to the segregation of null alleles or the presence of too many alleles (20) in a low-detection population sample. These 16 microsatellite markers may be useful in the analysis of genetic applications for $O$. marmoratus.

\begin{tabular}{|c|c|c|c|c|c|c|c|c|c|}
\hline Locus & Repeat motif & Primer sequences $\left(5^{\prime}-3^{\prime}\right)$ & $\begin{array}{c}\text { Size } \\
\text { range (bp) }\end{array}$ & $\mathrm{Ta}\left({ }^{\circ} \mathrm{C}\right)$ & $N_{\mathrm{A}}$ & $H_{\mathrm{O}}$ & $H_{\mathrm{E}}$ & $\mathrm{P}$ (HWE) & $\begin{array}{l}\text { Accession } \\
\text { No. }\end{array}$ \\
\hline H113 & $(\mathrm{CA})_{11}$ & $\begin{array}{l}\text { F: HEX - GGAAGCTGCTGACCTTGACTC } \\
\text { R: CCTATGGTCCGTCCAGAGTGT }\end{array}$ & $148-188$ & 60 & 10 & 0.6604 & 0.7182 & 0.1519 & JF264394 \\
\hline H137 & $(\mathrm{GT})_{9}$ & $\begin{array}{l}\text { F: FAM - GATCAGAGGGTTCAGAAAGCAG } \\
\text { R: CATTACAGCACCGACAGAGGA }\end{array}$ & $210-236$ & 58 & 4 & 0.2075 & 0.2209 & 0.5780 & JF264402 \\
\hline $\mathrm{H} 27$ & $(\mathrm{TG})_{21} \mathrm{~N}_{105}(\mathrm{AC})_{5 \mathrm{v}}$ & $\begin{array}{l}\text { F: TAMRA - GATCAACAGTGTTTGCGTTAGG } \\
\text { R: TCTCACCTGATGGAAAGATGG }\end{array}$ & $242-302$ & 56 & 13 & 0.7358 & 0.7686 & 0.2894 & JF264376 \\
\hline H60 & $(\mathrm{GT})_{13} \mathrm{~N}_{15}(\mathrm{TG})_{6}$ & $\begin{array}{l}\text { F: HEX - GTTTGGCTGAAATGGTAGTGTG } \\
\text { R: TGGAATGATGCTAGTGGCTGT }\end{array}$ & $160-200$ & 56 & 3 & 0.0943 & 0.1255 & 0.0854 & JF264381 \\
\hline H167 & $(\mathrm{AC})_{9} \mathrm{~N}_{73}(\mathrm{AC})_{6}$ & $\begin{array}{l}\text { F: FAM - TCCATTACAGCACCGACAGAG } \\
\text { R: GATCAGAGGGTTCAGAAAGCAG }\end{array}$ & $220-232$ & 58 & 3 & 0.2830 & 0.3245 & 0.5791 & JF264409 \\
\hline H63 & $(\mathrm{AC})_{5} \mathrm{AG}(\mathrm{AC})_{7}$ & $\begin{array}{l}\text { F: TAMRA - AGAGCAGGCGTTAGCAAGAC } \\
\text { R: AGATTAGAGGACGGAGGGAGA }\end{array}$ & $302-303$ & 58 & 2 & 0.0377 & 0.0370 & 1.0000 & JF264382 \\
\hline H94 & $(\mathrm{TG})_{12}$ & $\begin{array}{l}\text { F: HEX - GAGGATTTCCCGCTTCTATG } \\
\text { R: GCCGTCTTTCTGTTTGTCTTG }\end{array}$ & $146-166$ & 56 & 5 & 0.2452 & 0.3012 & 0.1256 & JF264391 \\
\hline Y12 & $(\mathrm{CA})_{7} \mathrm{~N}_{4}(\mathrm{CA})_{6}$ & $\begin{array}{l}\text { F: FAM - ATTATGATCCCCCACCAGCT } \\
\text { R: TGTGATTGTCCCCTCTCACAG }\end{array}$ & $207-229$ & 57 & 3 & 0.3208 & 0.3859 & 0.2631 & JF419699 \\
\hline H117 & $(\mathrm{CA})_{8} \mathrm{~N}_{111}(\mathrm{CA})_{5}$ & $\begin{array}{l}\text { F: TAMRA - ATAGCTCTGCGACGTGATTGG } \\
\text { R: GGACTTAGCTTTACCCTGTGGA }\end{array}$ & $276-286$ & 58 & 4 & 0.3962 & 0.4381 & 0.4815 & JF264411 \\
\hline H138 & $(\mathrm{TC})_{5}(\mathrm{AC})_{13}$ & $\begin{array}{l}\text { F: HEX - TAAGCCAGTGCCAGCAGAGT } \\
\text { R: GCCCTGATTGTGACTGTGGAG }\end{array}$ & $138-172$ & 58 & 6 & 0.4717 & 0.4963 & 0.3953 & JF264403 \\
\hline H191 & $\begin{array}{l}(\mathrm{AC})_{11} \mathrm{~N}_{51}(\mathrm{GA})_{10} \\
\mathrm{~N}_{0}(\mathrm{TG})_{4} \mathrm{~T}_{2}(\mathrm{TG})_{6}\end{array}$ & $\begin{array}{l}\text { F: FAM - TGACATCTGTCCTGGCTTCG } \\
\text { R: GCCTGCGTCTTTGACAACTC }\end{array}$ & 254-288 & 58 & 15 & 0.7170 & 0.8033 & 0.2897 & JF264413 \\
\hline H56 & $(\mathrm{AC})_{12}$ & $\begin{array}{l}\text { F: TAMRA - GCGAATTGCTGCAAGTGAGA } \\
\text { R: GGTTGGGAGGAAGTGTTAGGA }\end{array}$ & $258-272$ & 56 & 6 & 0.2453 & 0.2424 & 0.5998 & JF264379 \\
\hline H142 & $\begin{array}{l}(\mathrm{CA})_{6} \mathrm{G}(\mathrm{AC})_{8} \\
\mathrm{~N}_{5}(\mathrm{CA})_{7}\end{array}$ & $\begin{array}{l}\text { F: HEX - GAAATTGGAACGGGAGGCA } \\
\text { R: ATGGGAGCCACGACTCACA }\end{array}$ & $93-123$ & 58 & 11 & 0.7547 & 0.7175 & 0.3493 & JF264405 \\
\hline H97 & $(\mathrm{CA})_{2}$ & $\begin{array}{l}\text { F: FAM - AATCTGGCTTGACGCACTCT } \\
\text { R: TTCCGCACGGTATCCTCTT }\end{array}$ & $191-263$ & 56 & 20 & 0.8491 & 0.8927 & $0.0445^{*}$ & JF264392 \\
\hline M351 & $(\mathrm{TTCAA})_{5}$ & $\begin{array}{l}\text { F: TAMRA - GATCCTTTGCTCTGTTTCAG } \\
\text { R: TCCTGGGTCTGTTTAGTGTAG }\end{array}$ & $247-293$ & 54 & 5 & 0.6981 & 0.6759 & 0.1523 & JF419693 \\
\hline H240 & $(\mathrm{TG})_{12}$ & $\begin{array}{l}\text { R: HEX - GAGGATTTCCCGCTTCTATG } \\
\text { F: CCGTCTTTCTGTTTGTCTTGAG }\end{array}$ & $167-177$ & 56 & 3 & 0.4151 & 0.5568 & 0.1927 & $\mathrm{JF} 264420$ \\
\hline
\end{tabular}

$N_{\mathrm{A}}=$ allele number; $H_{\mathrm{O}}=$ observed heterozygosity; $H_{\mathrm{E}}=$ expected heterozygosity; HWE = Hardy-Weinberg equilibrium. Statistically significance at $* \mathrm{P}<0.05$. 


\section{ACKNOWLEDGMENTS}

Research supported by the National Research Funding Project for Agricultural Commercialization (\#2010GB2E200377), the National Spark Program Project (\#2011GA690368), the Natural Science Foundation of Hainan Province (\#310037), the Scientific Foundation of Hainan University (\#kyqd1018), and the Priority Academic Program Development of Jiangsu Higher Education Institutions (PAPD), China.

\section{REFERENCES}

Abercrombie LG, Anderson CM, Baldwin BG, Bang IC, et al. (2009). Permanent Genetic Resources added to Molecular Ecology Resources database 1 January 2009-30 April 2009. Mol. Ecol. Resour. 9: 1375-1379.

Kottelat M, Whitten AJ, Kartikasari SN and Wirjoatmodjo S (1993). Freshwater Fishes of Weatern Indonesia and Sulawesi. Periplus Editions, Hong Kong.

Li Q and Wan JM (2005). SSRHunter: development of a local searching software for SSR sites. Yi Chuan 27: 808-810.

Moraga AD, Farmerie B, Holland K and Blake A (1998). Tools for Developing Molecular Markers: Microsatellite Libraries and AFLPS. Workshop Manual. University of Florida, Gainesville.

Nakagawa Y, Eguchi M, Ching FF, Senoo S, et al. (2009). Grazing of protozooplankton assemblages on microalgae in the rearing water of the marble goby, Oxyeleotris marmoratus, during early larval rearing. Aquaculture Sci. 57: 71-75.

Raymond M and Rousset F (1995). GENEPOP (version 1.2): population genetics software for exact tests and ecumenicism. J. Heredity 86: 248-249.

Rousset F (2008). Genepop'007: a complete re-implementation of the genepop software for Windows and Linux. Mol. Ecol. Resour. 8: 103-106.

Smith HM (1945). The freshwater fishes of Siam, or Thailand. Smithson Inst., U.S. Nat. Mus. Bull., Washington.

Su SL, Mohd AA, Ahmad J and Ah TL (2008). Waste excretion of marble goby (Oxyeleotris marmorata Bleeker) fed with different diets. Aquaculture 274: 49-56.

Vu CL, Yang Y and Chang KL (2005). Cove culture of marble goby (Oxyeleotris marmorata Bleeker) and carps in Tri An Reservoir of Vietnam. Aquaculture 244: 97-107.

Yeh FC, Yang RC and Boyle T (1999). POPGENE Version 1.31. Population Genetics Software. Available at [http://www. ualberta.ca/*fyeh/fyeh/]. Accessed May 12, 2009.

Zane L, Bargelloni L and Patarnello T (2002). Strategies for microsatellite isolation: a review. Mol. Ecol. 11: 1-16. 